\title{
Creation of Zero Carbon Emissions Wastewater Treatment Plants - A Case Study in Crete, Greece
}

\author{
John Vourdoubas ${ }^{1}$ \\ ${ }^{1}$ Mediterranean Agronomic Institute of Chania, Agrokipio, 73100, Chania, Crete, Greece \\ Correspondence: John Vourdoubas, Mediterranean Agronomic Institute of Chania, Agrokipio, 73100, Chania, \\ Crete, Greece.Tel: 30-28210-35020, Fax: 30-28210-35001. E-mail: vourdoubas@maich.gr
}

Received: April 16, 2018

Accepted: April 25, $2018 \quad$ Online Published: May 11, 2018

doi:10.5539/eer.v8n1p64

URL: https://doi.org/10.5539/eer.v8n1p64

\begin{abstract}
Wastewater treatment plants use energy intensive processes for removing pollutants, consuming large amounts of electricity and emitting greenhouse gases. The possibility of zeroing carbon emissions due to energy use in these plants has been investigated in the current work with reference to the municipal treatment plant of Chania on the island of Crete, Greece. The sewage treatment plant processes $19,400 \mathrm{M}^{3}$ daily consuming $0.543 \mathrm{KWh}$ per $\mathrm{M}^{3}$ or $3840 \mathrm{MWh}$ annually. The use of locally available renewable energies has been proposed for electricity generation combined with co-generation of heat and power from the biogas already produced in the plant with sludge digestion. Installation of solar-PV systems and wind turbines in the plant could generate electricity, each equal to $25 \%$ of the annual electricity consumption in the plant. Additionally, biogas use can cover all the heating needs in the plant and can generate electricity corresponding at $20 \%$ of the total annual grid electricity use. Creation of a tree plantation, irrigated by the treated effluent, of 118.4 hectares, has been proposed which could annually offset carbon emissions due to the remaining grid electricity use. Creation of the tree plantation will create additional benefits, due to existing land desertification in Crete, additionally to carbon sequestration. The size of the required solar-PV and wind turbine systems has been estimated at $640 \mathrm{KWp}$ and $391 \mathrm{KW}$ and their cost at 0.832 mil $€$ and 0.430 mil $€$ correspondingly. Current work indicates that the combined use of solar energy, wind energy, biogas and carbon sequestration with tree plantations could zero carbon emissions in the municipal sewage treatment plant of Chania, Crete.
\end{abstract}

Keywords: biogas, carbon emissions, Crete, energy consumption, sewage treatment, solar energy, tree plantations, wind energy

\section{Introduction}

Wastewater treatment using the activated sludge process requires large amounts of energy for removing the contained pollutants. For providing the necessary heat and electricity, conventional fuels are mainly used in sewage treatment plants, resulting in $\mathrm{CO}_{2}$ emissions. However the current necessity to mitigate the greenhouse effect has increased the global interest and the efforts to reduce with various ways the energy consumption and the carbon emissions in those plants or even to transform them to net-zero energy and/or net-zero carbon emission plants.

\subsection{Energy Consumption in WWTPs}

Energy consumption in wastewater treatment plants (WWTPs) in China has been reported by Tao et al, 2012. The authors have analyzed data from 1856 plants in 2009 and they have estimated an average energy consumption at $0.254 \mathrm{KWh} / \mathrm{M}^{3}$. They have also reported that the aeration stage had a share of more than half the total energy consumption. Hopkowicz, 2000 estimated the energy consumption of a WWTP in NowySacz, Poland. The author reported that its energy consumption was $0.378 \mathrm{KWh} / \mathrm{M}^{3}$ and that the share of the energy used in the biological treatment phase of the total energy consumption was $72 \%$. Singh et al, 2012 presented an energy pattern analysis of a WWTP. The authors studied small scale WWTPs, estimating their overall energy consumption at 1.046 $\mathrm{KWh} / \mathrm{M}^{3}$. They reported that the share of electricity consumption is approximately $50 \%$ of the total energy use whilethe manual energy consumption is $32 \%$ of the total. De Haas et al, 2015 reported on the energy efficiency of the WWTPs in Australia. The authors studied the energy consumption in twelve (12) Australian WWTPs using the activated sludge process. They estimated that their electrical energy consumption varied from $0.323 \mathrm{KWh} / \mathrm{M}^{3}$ to $1.701 \mathrm{KWh} / \mathrm{M}^{3}$. The authors concluded that Australian WWTPs could improve their energy efficiency through self-supply systems, particularly co-generation of heat and power from biogas. Maslon, 2017 analyzed the energy 
consumption at the Rzeszow WWTP in Poland. He stated that the cost of energy in WWTPs reaches up to $40 \%$ of their total operating costs; in activated sludge processes approximately $50 \%$ of the total energy use corresponds to aeration and mixing. The author estimated the total energy consumption at $0.865 \mathrm{KWh} / \mathrm{M}^{3}$ while electricity consumption was at $0.468 \mathrm{KWh} / \mathrm{M}^{3}$ and heat consumption at $0.397 \mathrm{KWh} / \mathrm{M}^{3}$. He also stated that anaerobic digestion and co-generation of heat and power (CHP) technology play an important role in energy self-sufficiency. The biogas use in the plant could meet $74.3 \%$ of the electricity requirements and $95.5 \%$ of the heat needs. Gikas et al, 2014 reported on near zero energy WWTPs for Greek islands stating that conventional sewage treatment plants require approximately 0.31 to $0.67 \mathrm{KWh}$ per $\mathrm{M}^{3}$ annually.The authors calculated the annual electric energy requirements for the sewage treatment plants in two Hellenic cities, in Volos and in Patras, with a slightly higher population than Chania, at 0.39-0.48 KWh per $\mathrm{M}^{3}$. Mamais et al, 2015 reported on energy saving and greenhouse gas (GHG) emissions in wastewater treatment processes. Analyzing the data from the operation of 10 WWTPs in Greece, with a capacity for $15000-4000000$ inhabitants, the authors have found that the total annual energy consumption varies from 0.16 to $0.94 \mathrm{KWh}$ per $\mathrm{M}^{3}$ with an average value at $0.42 \mathrm{KWh}$ per $\mathrm{M}^{3}$. An evaluation of the energy efficiency in a large WWTP in Italy has been reported by Panepinto et al, 2016. The authors reported that the electricity share to the total energy consumption was $57.60 \%$ while $50 \%$ of it was attributed to the aeration stage. Heat energy share was at $42.40 \%$ while $93 \%$ of it was attributed to sludge processing.

\subsection{Biogas Production and Utilization in WWTPS}

Sustainable biogas production in municipal WWTPs has been reported by Bachmann, 2015. The author investigated the sustainable technologies which can improve the energy efficiency as well as biogas production and utilization in those plants. She stated that higher energy autonomy can be obtained in larger plants. She also reported that heat autonomy is easily achievable at $90-100 \%$ with electricity autonomy at 37\% in WWTPs with less than 100000 equivalent population (E.P.). In larger plants with more than 100000 E.P., electricity autonomy could reach $68-100 \%$ while total energy autonomy is achieved in very large and sophisticated plants. Shen et al, 2015 have reported on biogas production and utilization in WWTPs in the United States (U.S.). The authors stated that currently biogas in most U.S. WWTPs is either flared or used on-site for heat and power co-generation. They proposed that sludge co-digestion with various organic wastes results in higher methane yield and more efficient digester volume utilization, increasing the overall energy efficiency. Silva Dos Santos et al, 2016 have reported on electricity generation from biogas in WWTPs in Brazil. The authors have analyzed the economic viability of electricity generation from biogas in WWTPs, indicating that this is viable only in cities with populations higher than 300000 inhabitants.

\subsection{Energy and Carbon Neutrality in WWTPs}

The challenges concerning the creation of energy self-sufficient WWTPs have been reported by Gu et al, 2017 . The authors reported that the average energy input in the conventional activated sludge process is $0,46 \mathrm{KWh} / \mathrm{M}^{3}$ in Australia, $0.269 \mathrm{KWh} / \mathrm{M}^{3}$ in China, $0.33-0.60 \mathrm{KWh} / \mathrm{M}^{3}$ in the U.S. and $0.13-1.89 \mathrm{KWh} / \mathrm{M}^{3}$ in Japan. They also stated that in most medium- and large-scale WWTPs, aeration takes up approximately $50-60 \%$ of the total electricity consumption. Energy self-sufficient WWTPs have been reported so far mainly in the U.S. and in Europe while the authors indicated that energy self-sufficiency is difficult to be achieved in low capacity WWTPs. Energy neutrality in WWTPs in New Zealand has been reported by MacDonald et al, 2017. The authors studied six WWTPs in the U.S. which had reduced or net-zero energy consumption in order to transfer the technology used in New Zealand. The plants were mainly using biogas for electricity generation and additionally, if needed, solar photovoltaic (solar-PV) systems. They concluded that the realization of zero carbon emissions WWTPs due to energy use is currently feasible. Wett et al, 2007 reported on energy self-sufficiency as a feasible concept for wastewater treatment systems. The authors have investigated the energy efficiency in existing WWTPs focused on central Europe. Their results indicated that the average energy saving potential is approximately $30-50 \%$ while the large scale WWTP in Strass, Austria reached a positive energy balance, having an electricity surplus at $8 \%$. Awe et al, 2016 reported on energy consumption and saving in WWTPs in Ireland. The authors stated that wastewater does not only contain pollutants but also potential energy which could be recovered, increasing their energy efficiency. The authors proposed two strategic options improving energy efficiency and self-sufficiency in those plants including technical and management strategies. Energy independence of a municipal wastewater treatment plant using green energy resources has been examined by Chae et al, 2013. The authors investigated, in a municipal WWTP with a capacity for $30000 \mathrm{M}^{3} /$ day, the use of a solar-PV system at $100 \mathrm{KWp}$, a $10 \mathrm{KW}$ hydroelectric system and an effluent heat recovery system. They concluded that green energy resources use in those plants must be tailored to specific site conditions. Wang et al, 2016 published a comparative analysis on energy intensity and carbon emissions in WWTPs in the U.S., Germany, China and South Africa. The authors stated that only a few WWTPs operating in developed countries (the U.S. and Germany) have already achieved almost $100 \%$ electricity 
self-sufficiency through increased energy efficiency and harvesting biogas and electricity. Additionally thermal energy from the wastewater can be produced. They concluded that net-zero electricity in WWTPs is feasible. McCarty et al, 2011 reported on domestic wastewater treatment as a net energy producer. The authors proposed a different way of treating sewage wastes in order to recover all the energy content of the wastewater. They stated that complete anaerobic treatment is more energy efficient than conventional aerobic treatment. However the transformation of the already existing WWTPs to anaerobic processing plants is costly. An evaluation of the potential for operating carbon neutral WWTPs in China has been reported by Hao et al, 2015. The authors stated that biogas from sludge digestion can provide approximately $50 \%$ of the total energy consumption in the plant. Water source heat pumps can utilize the heat energy of the wastes producing heat distributed in nearby located buildings. Therefore part of the energy consumed in the plant could be offset by thermal energy production. Finally solar-PV systems can generate electricity; however the authors did not suggest their use. They concluded that the combined utilization of biogas energy and thermal energy with heat pumps could achieve the target of carbon neutral operation in those plants. Stillwell et al, 2010 reported on energy recovery from WWTPs in the U.S. The authors stated that energy recovery strategies including anaerobic digestion combined with biogas utilization and bio-solids incineration combined with electricity generation could offset the electricity consumption in WWTPs. They have also estimated that the abovementioned processes could reduce electricity consumption in those plants by $4.7-83 \%$ in the state of Texas, U.S. The WWTP of Chania, Crete, Greece is located a few kilometers east of the city and it can serve a population of 170000 inhabitants treating, during 2017, $19400 \mathrm{M}^{3}$ daily (Personal communication). Treatment of the wastes is obtained with the activated sludge process and the sludge produced is treated anaerobically for biogas production. Biogas is used for CHP generating heat and electricity, increasing the energy efficiency of the plant. Treated effluent is currently disposed into the sea but it could also be used for irrigation of tree plantations in the nearby area. Kyung et al, 2015 estimated GHG emissions in a WWTP. The authors reported that on-site GHG emissions are almost double the corresponding off-site emissions in these plants.

\subsection{Carbon Sequestration in Tree Plantations}

A report on the impacts of forest plantations in offsetting carbon emissions due to fossil fuels use has been presented by Zhao et al, 2010. The authors estimated that annual carbon sequestration in urban forests in Hangzhou, China was at 1.66 tons of carbon $(\mathrm{tC})$ per hectare (ha). Nowak et al, 2002 reported on carbon sequestration in urban trees in the U.S. The authors estimated that annual carbon sequestration in urban forests in the U.S. is 0.8 tC per ha. They also mentioned that carbon sequestration in urban forests is significantly lower than in typical forests. Nardino et al, 2013 reported on carbon sequestration in a Mediterranean olive orchard. The authors estimated the annual carbon accumulation in those trees in the Mediterranean region at $11.6 \mathrm{tC}$ per ha up to 13.45 tC per ha. They concluded that the intensive farming management and the young age of the plants in the olive plantation resulted in high carbon accumulation compared with other tree plantations reported in the literature. Wastewater and grey water reuse in irrigation has been reported by Matos et al, 2014. The authors compared a wastewater centralized reuse system and a grey-water decentralized reuse system concerning energy consumption and $\mathrm{CO}_{2}$ emissions. They concluded that the grey-water decentralized reuse system consumes significantly less energy, between $11.8 \%$ and $37.5 \%$ of the energy consumed in the same capacity wastewater centralized reuse system.

The aims of the current work are:

a) The estimation of energy consumption in various existing WWTPs worldwide and the possibility of using on-site or off-site renewable energy sources for increasing their energy self-sufficiency,

b) The investigation of the possibility of using solar energy, wind energy and biogas for heat and electricity generation in WWTPs,

c) The investigation of the possibility of using the treated effluent of WWTPs for irrigation of tree plantations resulting in carbon sequestration through photosynthesis, and

d) The investigation of the possibility of using various renewable energies generating heat and electricity in the WWTP in Chania, Crete, Greece in order to zero its carbon emissions due to energy use.

\section{Possibility of Using Various Renewable Energy Technologies in the WWTP of Chania for Increasing its Energy Self-Sufficiency}

Various renewable energy technologies could be used in the WWTP of Chania in order to increase its energy selfsufficiency and to reduce or zero its carbon emissions due to energy use. The use of these technologies is site- 
dependent and includes the utilization of biogas produced in the plant for heat and power generation as well as installation of solar-PV systems and wind turbines for electricity generation. Additionally the recycling of the treated effluent for the irrigation of tree plantations could offset carbon emissions produced during electricity generation from fossil fuels.

\subsection{Biogas Production and Utilization}

The WWTP of Chania includes a sludge digestion unit consisting of four (4) digestors with a total volume of 6200 $\mathrm{M}^{3}$. The temperature of anaerobic digestion is at $35^{\circ} \mathrm{C}$ and the biogas produced contains $65-68 \%$ methane which is burnt in a CHP unit generating heat, which is used for heating the digestors, and electricity which is fed into the grid (Personal communication). Although current studies have indicated that biogas production and utilization is profitable in large WWTPs with E.P. of more than 200000 inhabitants, the presence of a sludge digestion system in the WWTP of Chania allows the production of heat and electricity. Addition of wastes with high organic content in the sludge could increase the biogas production.

\subsection{Solar-PV Electricity Generation}

The high solar irradiance in Crete facilitates the in-situ solar electricity generation for covering part of its electricity needs. Solar-PV technology is a well-proven, reliable, mature and cost-effective technology. Currently there are many solar-PV systems installed in Crete generating part of the electricity consumption in the island. The required space in order to install a solar-PV system in-situ exists in the WWTP of Chania. Alternatively installation of offsite solar-PV systems is feasible according to the current legal framework in Greece.

\subsection{Wind Electricity Generation}

Installation of wind turbines in the treatment plant of Chania is feasible since there is space availability. However past measurements of the annual wind velocity on-site have shown that it is low, at 3-4 $\mathrm{m} / \mathrm{sec}$ (Personal communication) and the installation of a wind turbine is not attractive. Therefore an attractive off-site location must be found for the installation of a wind turbine. Electricity generated should be fed into the grid, increasing the electricity self-sufficiency of the treatment plant.

\subsection{Carbon Sequestration by Tree Plantations}

The processed effluent from the treatment plant contains valuable nutrients necessary for plant growth. Currently it is disposed into the sea creating pollution problems. However the recycling of the treated water and the nutrients contained is desirable. Lack of sufficient water resources in Crete combined with land desertification increases the challenges for recycling the treated effluent. European policies are focused in the promotion of the circular economy and in the increase of resource efficiency. Taking into account that available land exists near to the treatment plant a tree plantation could be created, irrigated by the treated effluent. The quality of the treated water in the WWTP is suitable for irrigation of various tree species according to current regulations. Various trees could be planted, preferably indigenous species. Growth of the tree plantation will remove atmospheric carbon dioxide through photosynthesis, counterbalancing carbon emissions during electricity generation with fossil fuels in Crete. Recycling of the processed effluent irrigating a new tree plantation will offer many environmental benefits including mitigation of climate change, reduction of land desertification, reduction of sea pollution and increasing the efficiency of water and nutrients utilization. It should be noted that electricity will be consumed for pumping and irrigation of the tree plantation with the processed effluent.

An overview of the above-mentioned technologies is presented in Table 1.

Table 1. Technologies which can be used in the WWTP of Chania for improving its energy self-sufficiency and reducing its carbon footprint

\begin{tabular}{lccc}
\hline Technology & Energy generated & $\begin{array}{c}\text { Does the system } \\
\text { already exists in the } \\
\text { WWTPs ? }\end{array}$ & Expected results \\
\hline $\begin{array}{l}\text { Biogas production and } \\
\text { utilization }\end{array}$ & Yes & $\begin{array}{c}\text { Heat is used in the } \\
\text { digestors, Co-generated } \\
\text { electricity is fed into } \\
\text { the grid }\end{array}$ \\
Solar-PV & Electricity & No & $\begin{array}{c}\text { Electricity is fed into } \\
\text { the grid }\end{array}$ \\
Wind turbines & Electricity & No & Electricity is fed into \\
\hline
\end{tabular}




\begin{tabular}{|c|c|c|c|}
\hline $\begin{array}{l}\text { Creation of a tree } \\
\text { plantation irrigated by } \\
\text { the processed effluent }\end{array}$ & $\begin{array}{l}\text { There is no energy } \\
\text { generation }\end{array}$ & No & $\begin{array}{c}\text { the grid } \\
\text { The tree plantation } \\
\text { removes atmospheric } \\
\mathrm{CO}_{2} \text { through plant } \\
\text { photosvnthesis }\end{array}$ \\
\hline
\end{tabular}

\section{Requirements for Zeroing Carbon Emissions Due to Energy Use in the WWTP of Chania}

In order to zero the carbon emissions due to operational energy use in WWTPs, the following criteria should be fulfilled:

a) Renewable energy sources should be used in the treatment plant, and/or

b) If energy derived from fossil fuels is used, like grid electricity, the same amount of electricity should be generated annually from renewable energy sources and fed into the grid, and/or

c) The same amount of $\mathrm{CO}_{2}$ emitted annually due to fossil fuel use in the plant should be removed by carbon sequestration from tree plantations irrigated with the processed effluent of the plant.

If though the life cycle $\mathrm{CO}_{2}$ emissions from the WWTP should be zeroed, the embodied energy additionally to the operational energy must be taken into account.

\section{Possibilities of Zeroing Carbon Emissions due to Energy Use in the WWTP of Chania}

The WWTP of Chania processed $19400 \mathrm{M}^{3}$ per day or $7081000 \mathrm{M}^{3}$ annually in 2017 (Personal communication). The following assumptions and estimations have been made in order to investigate the possibilities of zeroing its carbon emissions due to energy use:

a) Its total annual electricity consumption is $0.543 \mathrm{KWh}$ per $\mathrm{M}^{3}$ or $3840 \mathrm{MWh}$ in total. The annual net grid electricity use, deducting the electricity generated in-situ by biogas, is $3072 \mathrm{MWh}$. Total annual $\mathrm{CO}_{2}$ emissions due to net grid electricity use are 2304 tons or $0.33 \mathrm{~kg} \mathrm{CO}_{2} / \mathrm{M}^{3}$.

b) Biogas produced in the plant is currently used for co-generation of heat and power. Generated heat covers all the heating needs in the digestors and the co-generated power, equal at $20 \%$ of its total annual electricity needs, at $768 \mathrm{MWh}$, is fed into the grid. Electricity generated by biogas results in annual savings of 576 tons of $\mathrm{CO}_{2}$.

c) $25 \%$ of the grid electricity use, that is $960 \mathrm{MWh}$, would be generated with a solar-PV system, and the remaining $25 \%$ with wind turbines.

d) Carbon emissions corresponding to $30 \%$ of the electricity use, that is $1152 \mathrm{MWh}$, would be offset with carbon sequestration from tree plantations irrigated with the plant's processed effluent.

e) Assuming that during the generation of $1 \mathrm{KWh}$ of grid electricity in Crete, $0.75 \mathrm{~kg} \mathrm{CO}_{2}$ are emitted, the total $\mathrm{CO}_{2}$ emissions during the generation of $1152 \mathrm{MWh}$ are 864 tons. Growth of the tree plantation will eliminate this amount of $\mathrm{CO}_{2}$ annually.

\subsection{Estimation of the Required Solar-PV System}

Taking into account that a solar-PV system at $1 \mathrm{KWp}$ in Crete generates $1500 \mathrm{KWh}$ annually, the size of a solar$\mathrm{PV}$ system generating $960 \mathrm{MWh}$ annually has been estimated at $640 \mathrm{KWp}$. Assuming that the cost of a solar-PV system is $1300 €$ per KWp, the capital cost of the $640 \mathrm{KWp}$ solar-PV system is estimated at 0.832 mil $€$.

\subsection{Estimation of the Required Wind Turbine System}

In order to size a wind turbine system generating the required electricity,it has been estimated that its capacity factor is 0.28 and the turbines annually generate $2453 \mathrm{KWh}$ per $\mathrm{KW}$. The size of the wind turbines generating 960 MWh annually has been found to be $391 \mathrm{KW}$, and assuming their unit cost at $1100 €$ per KW, their total capital cost is 0.430 mil. $€$.

\subsection{Estimation of the Required Tree Plantation for Carbon Sequestration}

The reported values in the literature regarding carbon sequestration by tree plantations vary considerably and it has been assumed that $2 \mathrm{tC}\left(7.3 \mathrm{tCO}_{2}\right)$ per ha of tree plantation in Crete can be removed annually. For annual removal of 1152 tons of $\mathrm{CO}_{2}$, a tree plantation in an area of 118.4 ha is required. This area is not currently available on-site in the treatment plant in Chania but it could be created in nearby areas.

The size of various energy systems and the tree plantation offsetting carbon emissions due to electricity use in the 
WWTP in Chania are presented in Table 2.

Table 2. Size of various sustainable energy systems and tree plantation offsetting $\mathrm{CO}_{2}$ emissions due to electricity use in the treatment plant of Chania

\begin{tabular}{|c|c|c|c|c|c|c|}
\hline $\begin{array}{l}\text { Electricity } \\
\text { generation } \\
\text { system }\end{array}$ & $\begin{array}{l}\text { Annual } \\
\text { Electricity } \\
\text { generation } \\
\quad(\mathrm{MWh})\end{array}$ & $\begin{array}{l}\text { Fossil fuel } \\
\text { electricity } \\
\text { emitting } \\
\text { the same } \\
\mathrm{CO}_{2} \\
\text { removed } \\
\text { by the tree } \\
\text { plantation } \\
\text { (MWh) }\end{array}$ & $\begin{array}{l}\text { Size of the } \\
\text { tree } \\
\text { plantation } \\
\text { (ha) }\end{array}$ & $\begin{array}{l}\text { Annual } \\
\mathrm{CO}_{2} \\
\text { savings } \\
\quad \text { (tons) }\end{array}$ & $\begin{array}{l}\text { Size of the } \\
\text { energy } \\
\text { systems }\end{array}$ & $\begin{array}{l}\text { Cost of the } \\
\text { energy } \\
\text { system } \\
\quad \text { (mil. } €)\end{array}$ \\
\hline $\begin{array}{l}\text { Biogas burning } \\
\text { system }\end{array}$ & 768 & & & 576 & & \\
\hline Solar-PV system & 960 & & & 720 & $640 \mathrm{KWp}$ & 0.832 \\
\hline Wind turbines & 960 & & & 720 & 391 KW & 0.430 \\
\hline Tree plantation & & 1152 & & 864 & & \\
\hline Total & 2668 & 1152 & 118.4 & 2880 & & 1.262 \\
\hline
\end{tabular}

${ }^{1}$ Carbon emissions during grid electricity generation are $0.75 \mathrm{~kg} \mathrm{CO}_{2}$ per $\mathrm{KWh}$

\section{Discussion}

Carbon emissions due to energy use in various sewage treatment plants depend on many factors including their size, the technology used and the energy efficiency of the equipment used. Zeroing $\mathrm{CO}_{2}$ emissions during the operation of municipal WWTPs using the activated sludge process is feasible and it has already been achieved in some large and technologically sophisticated plants. Increase in their energy efficiency is a prerequisite for achieving zero carbon emission treatment plants. Sludge digestion for biogas production is economically viable in plants with a capacity higher than 200000 inhabitants. However biogas production and utilization is very important for energy self-sufficiency. It can be used for co-generation of heat and power covering part of their energy needs. Sludge can be enriched with liquid wastes with high organic content like wastes from slaughter houses and/or cheese-making plants, if they are available, resulting in higher biogas and energy yields. In small-scale WWTPs, biogas utilization can cover all the heating needs and up to $37 \%$ of the electricity needs. Various renewable energy sources, depending on their availability in the specific site conditions, can be used. They include solar and wind energy for power generation, particularly in areas with high solar irradiance and high annual wind speed velocities. Utilization of the thermal energy of the liquid wastes with high efficiency heat pumps for heat and cooling production can improve the carbon balance. Heat and cooling can be used in urban buildings located nearby, if they exist, for offsetting carbon emissions in the WWTP. Bio-solids produced after sludge stabilization can be burnt for power generation or CHP, providing additional energy to biogas utilization. Carbon emissions can also be eliminated by carbon sequestration from tree plantations irrigated from the treated effluent. Tree plantations can be created in nearby areas, if there is availability, and they result in additional environmental benefits like mitigation of land desertification and improvement of the local ecosystem. Therefore there are various approaches which can assist in the achievement of zero $\mathrm{CO}_{2}$ emissions WWTPs due to energy use, including:

a) Increase of the energy efficiency in the plant,

b) Utilizing the biogas produced from sludge digestion and increasing its yield with appropriate mixing with various other wastes having high organic content,

c) Use of solar-PV technology,

d) Use of wind power technology,

e) Burning of the bio-solids (dried sludge) produced for electricity generation,

f) Use of high efficiency heat pumps utilizing the low enthalpy heat of the liquid wastes in the plant for the production of heat and cooling, and

g) Offsetting $\mathrm{CO}_{2}$ emissions in the plant with carbon sequestration from tree plantations irrigated by the treated 
effluent.

\section{Conclusions}

Energy consumption in WWTPs globally has been reported between 0.2 to $1.9 \mathrm{KWh} / \mathrm{M}^{3}$ while in Greece it is between 0.31 to $0.67 \mathrm{KWh} / \mathrm{M}^{3}$. Annual electricity consumption in the sewage treatment plant of Chania has been estimated at $0.543 \mathrm{KWh} / \mathrm{M}^{3}$ and its current annual $\mathrm{CO}_{2}$ emissions due to grid electricity use at $0.33 \mathrm{~kg} \mathrm{CO} / \mathrm{M}^{3}$. A few energy self-sufficient WWTPs already exist in advanced countries which are large with technologically sophisticated plants. Sludge digestion for biogas production and its use for co-generation of heat and power is important for increasing its energy self-sufficiency and reducing its carbon emissions. However, biogas production is economically viable only in treatment plants with a capacity higher than 200000 inhabitants. Various renewable energy systems installed either on-site or off-site can be used for electricity generation like solar-PV and wind power systems. Energy offset in the plant can be achieved if high efficiency heat pumps will utilize the heat energy of the liquid wastes to generate heat and cooling used in buildings located nearby. Carbon emissions can also be offset if the treated wastes of the plant will irrigate a tree plantation resulting in carbon sequestration with photosynthesis. The municipal sewage treatment plant of Chania can obtain carbon neutrality due to energy consumption with the combined use of various renewable energies, including biogas, solar and wind energy, either on-site or off-site, and the additional offsetting of carbon emissions with the creation of a tree plantation. Biogas use will have a share of $20 \%$ in $\mathrm{CO}_{2}$ offset, solar and wind energy will have $25 \%$ each, while tree plantation will offset $30 \%$ of $\mathrm{CO}_{2}$ emissions. Due to high solar irradiance and the high annual wind velocities in Crete, solar-PV systems and wind turbines are cost-effective and they are already extensively used in the island for electricity generation. The quantity of biogas already produced in the plant from sludge digestion can be increased with the addition of various wastes rich in organic matter which are available nearby. The size of the required solar-PV system has been estimated at $640 \mathrm{KWp}$, with the size of the required wind energy system at $391 \mathrm{KW}$, while the size of the tree plantation is at 118.4 ha. The cost of the solar-PV system has been estimated at 0.832 mil. $€$ while the cost of the wind turbine system is estimated at 0.430 mil $€$. Further work should be focused in the investigation of the possibility of increasing the energy efficiency of the plant using more efficient machinery. If the energy efficiency of the plant is to be improved, then the size of the required renewable energy systems for achieving carbon neutrality would be reduced.

\section{Acknowledgements}

I would like to express my thanks to Mr. Michalis Kavroulakis and Mrs Christina Kotsifaki for providing recent data regarding the operation of the sewage treatment plant in Chania.

\section{References}

Aue, O. W., Liu, R., \& Zhao, Y. (2016). Analysis of energy consumption and saving in wastewater treatment plant: A case study from Ireland, Journal of Water Sustainability, 6(2), 63-76. https://doi.org/10.11912/jws.2016.6.2.63-76

Bachmann, N. (2015). Sustainable biogas production in municipal wastewater treatment plants, Technical Brochure, IEA Bioenergy. Retrieved March 15, 2018, from http://task37.ieabioenergy.com/files/datenredaktion/download/Technical\%20Brochures/Wastewater_biogas_grey_web-1.pdf

Chae, K. J., \& Kang, J. (2013). Estimating the energy independence of a municipal wastewater treatment plant incorporating green energy resources. Energy Conversion and Management, 75, 664-672. http://dx.doi.org/10.1016/j.enconman.2013.08.028

De Haas, D., \& Dansey, M. (2015). Wastewater treatment energy efficiency. A review with current Australian perspectives, technical paper, p. 53-58. Retrieved March 16, 2018, from http://www.watercentre.org/awajournal-november-2015-article/

Gikas, P., \& Tsoutsos, T. (2014). Near zero energy wastewater treatment plants for the Greek islands. Desalination and Water Treatment, 53(12), 3328-3334. https://doi.org/10.1080/19443994.2014.934109

Gu, Y., Li, Y., Li, X., Luo, P., Wang, H., Wang, X., Wu, J., \& Li, F. (2017). Energy self-sufficiency wastewater treatment plants: Feasibilities and challenges. Energy Procedia, 105, 3741-3751, https://doi.org/10.1016/j.egypro.2017.03.868

Hao, X., Liu, R., \& Huang, X. (2015). Evaluation of the potential for operating carbon neutral WWTPs in China. Water Research, 87, 424-431. http://dx.doi.org/10.1016/j.watres.2015.05.050

Hopkowicz, M. (2000). Energy management at WWTP with biogas utilization. In: Proceedings of a PolishSwedish seminar, Cracow, May 29, 2000. Sustainable Municipal Sludge And Solid Waste Handling, E. Plaza, 
E. Levlin, B. Hultman, (Editors), TRITA-AMI REPORT 3073, ISSN 1400-1306, ISRN KTH/AMI/REPORT 3073-SE, ISBN 91-7170-584-8. 2000. http://www2.lwr.kth.se/forskningsprojekt/Polishproject/JPS7s43.pd

Kyung, D., Kim, M., Chang, J., \& Lee, W. (2015). Estimation of greenhouse gas emissions from a hybrid wastewater treatment plant. Journal of Cleaner Production, 95, 117123.http://dx.doi.org/10.1016/j.jclepro.2015.02.032

Mamais, D., Noutsopoulos, C., Dimopoulou, A., Stasinakis, A., \& Lekkas, T. D. (2015). Water treatment process impact on energy savings and greenhouse gas emissions. Water Science and Technology, 71(2), 303-308, https://doi.org/10.2166/wst.2014.521

Maslon, A. (2017). Analysis of energy consumption at the Rzeszow wastewater treatment plant, E3S Web of Conferences. ASEE17, 22. https://doi.org/10.1051/e3sconf/20172200115

Matos, C., Pereira, S., Amorim, E.V., Bentes, I., \& Briga-Sa, A. (2014). Wastewater and greywater reuse on irrigation in centralized and decentralized systems-An integrated approach on water quality, energy consumption and $\mathrm{CO}_{2}$ emissions. Science of the Total Environment, 493, 463-471. http://dx.doi.org/10.1016/j.scitotenv.2014.05.129

McCarty, P. L., Bae, J., \& Kim, J. (2011). Domestic wastewater treatment as a net energy producer-Can this be achieved ? Environmental Science and Technology, 45, 7100-7106. https://doi.org/10.1021/es2014264

McDonald, G., \& Crawford, J. (2017). Energy neutral WWTPs - A dream or a reality for New Zealand, in water New Zealand conference and Expo 2017. Retrieved March 15, 2018, from https://www.waternz.org.nz/Attachment?Action=Download\&Attachment_id=2798

Nardino, M., Pernice, F., Rossi, F., Georgiadis, T., Facini, O., Motisi, A., \& Drago, A. (2013). Annual and monthly carbon balance in an intensively managed Mediterranean olive orchard. Photosynthetica, 51(1), 63-74. https://doi.org/10.1007/s11099-012-0079-6

Nowak, D. J., \& Crane, D. E. (2002). Carbon storage and sequestration by urban trees in the U.S.A. Environmental Pollution, 116, 381-389. https://doi.org/10.1016/S0269-7491(01)00214-7

Panepinto, D., Fiore, S., Zappone, M., Genon, G., \& Meucci, L. (2016). Evaluation of the energy efficiency of a large wastewater treatment plant in Italy. Applied Energy, 161, 404-411. http://dx.doi.org/10.1016/j.apenergy.2015.10.027

Shen, Y., Linville, J. L, Urgun-Demirtas, M., Mintz, M. M., \& Synder, S. W. (2015). An overview of biogas production and utilization at full scale wastewater treatment plants (WWTPs) in the United States: Challenges and opportunities towards energy-neutral WWTPs. Renewable and Sustainable Energy Reviews, 50, 346-362. http://dx.doi.org/10.1016/j.rser.2015.04.129

Silva, Dos, Santos, I. F., Barros, R. M., \& Tiago, F. G. L. (2016). Electricity generation from biogas of anaerobic wastewater treatment plants in Brazil: an assessment of feasibility and potential. Journal of Cleaner Production, 126, 504-514. http://dx.doi.org/10.1016/j.jclepro.2016.03.072

Singh, P., Marquet, C. C., \& Kansal, A. (2012). Energy pattern analysis of a wastewater treatment plant. Applied Water Science, 2, 221-226. https://doi.org/10.1007/s13201-012-0040-7

Stillwell, A.S., Hoppock, D.C. \& Webber, M.E. (2010). Energy recovery from wastewater treatment plants in the United States: A case study of the energy-water nexus. Sustainability, 2, 945-962. https://doi.org/10.3390/su2040945

Tao, X., \& Chengwen, W. (2012). Energy consumption in wastewater treatment plants in China, In world Congress on Water, Climate and Energy, Dublin, Ireland._https://doi.org/10.13140/2.1.1228.9285

Wang, H., Yang, Y., Keller, A.A., Li, X., Feng, S., Dong, Y., \& Li, F. (2016). Comparative analysis of energy intensity and carbon emissions in wastewater treatment in USA, Germany, China and South Africa. Applied Energy, 184, 873-881. https://doi.org/10.1016/j.apenergy.2016.07.061

Wett, B., Buchauer, K., \& Fimml, C. (2007). Energy self-sufficiency as a feasible concept for wastewater treatment systems, Asian Water, 22-25. Retrieved March 15, 2015, from http://www.araconsult.at/download/literature/let07_wett_energy_selfsufficiency3.pdf

Zhao, M., Kong, Z. H., Escobedo, F. J., \& Gao, J. (2010). Impacts of Urban forests on offsetting carbon emissions from industrial energy use in Hangzhou, China, Journal of Environmental Management, 91, 807-813. https://doi.org/10.1016/j.jenvman.2009.10.010 


\section{Copyrights}

Copyright for this article is retained by the author(s), with first publication rights granted to the journal.

This is an open-access article distributed under the terms and conditions of the Creative Commons Attribution license (http://creativecommons.org/licenses/by/4.0/). 